\title{
1990 SONRASI MOĞOLİSTAN VE AMERİKA BİRLEŞİK DEVLETLERİ ÍLIŞKILERI
}

\author{
* Kaan DIYYARBAKIRLIOĞLU \\ ** Tuğçem KARAMAN
}

\section{Özet}

Moğolistan 1990 sonrası dış politika ilişkilerinde Amerika Birleşik Devletleri üzerine odaklanmıştır. Özellikle siyasi ilişkilerin gelişimi ve ekonomik desteğin arttırılması; Moğolistan'ın demokratikleşmesini ve modernleşmesini sağlamıştır. Çalışmada, Moğolistan'ın küçük devletler yaklaşımı konusundaki tutumu ve etkileri incelenmiş; siyasi ve ekonomik ilişkilerin önemi vurgulanmıştır. Bu bağlamda araştırmanın amacı, Moğolistan'ın dış politikasında ABD’nin siyasi ve ekonomik öneminin incelenmesidir.

Anahtar Kelimeler: Moğolistan, ABD, Üçüncü Komşu Politikas1, Moğolistan'ın Denge Politikas1.

\begin{abstract}
In the post-1990 foreign policy, Mongolia has focused on relations with the US. Especially the development of political relations and the increase of economic support; It has provided Mongolia's democratization and the modernization. The effects of Mongolia's attitude toward the Small States Approach were examined and the importance of political and economic relations was emphasized. In this context, the aim of the study is the examination of the US's political and economic importance of Mongolia's foreign policy.
\end{abstract}

Keywords: Third Neighbour Policy, Mongolian Balance Policy, Economic and Political Relations

* Yrd. Doç. Dr., Yalova Üniversitesi, IïBF, Uluslararası Ilişkiler Öğretim Üyesi

* *Uluslararası İlişkiler Yüksek Lisans Öğrencisi, Sosyal Bilimler Enstitüsü, Yalova Üniversitesi 


\section{Giriş}

1990’lar uluslararası ilişkiler için yeni bir sayfaya geçişi ifade etmektedir. Uluslararası sistemde yer alan gerek büyük gerekse küçük aktörlerin politikalarını ve sistemdeki davranışlarını belirleyen önemli siyasi dönüşümleri içeren bu yıllar, devletlerin dış politikalarının bugün bile korunan çerçevelerinin çizilmesinde önemli rol oynamıştır. Moğolistan mercek altına alındığında, devletin tüm özelliklerini ve tercihlerini belirleyen en önemli faktörün konumlandığı yer olduğu göze çarpmaktadır. Uzun yıllar Rusya ve Çin arasında yaşadığı siyasi, ekonomik, sosyolojik, askeri sorunlar Moğolistan'ın bağımsızlığından sonra da etkilerini sürdürmüştür ve bugün bile bağımsız bir devlet olmasına karşılık bu iki büyük güce göre politikasını ayarlamadığı takdirde güvenliğini tam olarak sağlayamayacağının farkında olan bir devlettir. Literatürde neorealist teori ve küçük devletler (small states) yaklaşımı yardımı ile yapılan okumalar, Moğolistan'ın dış politika analizinin kilit unsurunun güvenlik kavramı olduğunu ortaya koymaktadır. Moğolistan'1n uluslararası sistemde güvenliğini nasıl sağladığı sorulduğunda ortaya çıkan cevaplar çoğunlukla "güç" unsurunun etrafında şekillenmektedir.

Moğolistan diş politikasını, küçük devletler (small states) ile ele almak devletin sistemdeki diğer aktörler ile ilişkilerini analiz ederken daha doğru sonuçlara ulaşmada yardımcı olacaktır. Küçük devletler yaklaşımında tanımlama yapmak çok zordur ve literatürde farklı ölçütlere göre farklı tanımlar bulunmaktadır. Bir devletin hangi güç grubuna ait olduğuna karar vermek için devletin yüzölçümü, nüfusu, coğrafyası, tarihi, ekonomik kaynakları gibi fiziksel özelliklerinden ziyade; sistem içinde gösterdiği davranışları ve uyguladığı politikalarının analizi daha doğru sonuçlar verecektir. Moğolistan da bu şekilde bir incelemeden geçirildiğinde, Rusya ve Çin ile olan komşuluk ilişkileri ve komşusu olmamasına rağmen ABD ile olan "Üçüncü Komşu Politikası" çerçevesindeki ilişkileri; küçük devletler yaklaşımına uygun bir politikaya sahip olduğunu ortaya koyacaktır. Bu da küçük güçlerin güvenliğini garanti altına alma amacı ile başvurduğu bir "üçüncü yol" arayışı olarak tanımlanmaktadır. Moğolistan küçük devletler yaklaşımındaki tanımlamalarda, fiziksel bağlamdaki tanımlamaların yanıltıcı olabileceğine dair örnek teşkil etmektedir. Moğolistan'ın Cengiz Han'a dayanan tarihi, geniş yüzölçümü, yeraltı kaynakları gibi unsurlarına rağmen; günümüz 
siyasi kararları ve davranışları, sistemde küçük devletler yaklaşımından bir role büründügünü göstermektedir.

Küçük devletlerin sistemdeki diğer aktörleri hesaba katmadan, istekleri ve idealleri doğrultusunda strateji belirlemesi mümkün değildir. Esas unsurun güvenlik olduğu bir alanda yalnız başına alınacak kararlar, Moğolistan'ı tehdit altında bırakacak sonuçlara yol açabileceği için, genel bağlamda küçük devletlerin karar verme aşamaları ile Moğolistan'ın karar verme aşaması benzerlik göstermektedir. Karar verme aşamalarında esas etkili olan devletin idealleri, istekleri, tarihi geçmişinin getirdikleri gibi milli unsurlar değil; devletin uluslararası sistemdeki çıkarlarıdır. Uluslararası sistemin güncel sorunlarına göre, küçük devlet siyasi ve ekonomik çıkarını maksimize etmesini sağlayacak stratejiyi seçmek durumunda kalmaktadır. Fakat küçük güç olmak her zaman dezavantaj demek değildir; eğer devlet stratejik adımlar atarak etrafındaki büyük güçler ile politikasına uygun olarak ilişkilerini düzenlerse, güvenliğini sağladığı gibi bölgede kilit bir ülke konumuna da ulaşabilir. Bu noktada iki ayrı davranış arasında ayrım yapılmalıdır. Söz konusu küçük devlet bir denge politikası mı uygulamaktadır, yoksa "bandwagonnig" olarak nitelendirilen davranışı mı sergilemektedir?² Denge politikası stratejik olarak kullanıldığında, sistemde hedeflenen ağırlığa kavuşulabilirken; büyük devletin etrafında uydu devlet gibi hareket ederek "bandwagon" davranışını gösterirse tam tersi bir sonuç ortaya çıkacaktır. Devlet küçük güç etiketinin avantaj mı, dezavantaj mı olacağını seçtiği davranışlarla belirlemektedir.

Moğolistan'ın dış politikası incelenirken, bahsedilen yöntem ve yaklaşımlar kadar jeopolitiğin de önemli olduğu görülmektedir. Moğolistan'dan herhangi bir küçük devlet gibi bahsetmenin, konumlandığg yere bakıldığında doğru olmadığ1 görülecektir. Küçük devletlerin, büyük güçlerin kontrolü altına girmesi için coğrafi uzaklığın bir önemi olmadığı aşikârdır. Büyük devletlerin politikaları doğrultusunda kontrol etmeleri gereken devletlere ulaşmaları, doğru hamleler sonucunda fiziki uzaklıklardan bağımsız bir süreç olarak işlemektedir. Fakat hedef devlet ne kadar yakınsa, süreç bölgesel çapta ilerleyeceği için daha kolay olacağı söylenebilir. Nitekim Moğolistan'a bakıldığında Rusya ve Çin coğrafi avantajlarıyla zaten asırlardır Moğolistan'1 
etkilemektedirler. Fakat küresel bir güç olan ABD’yi buraya üçüncü komşu olacak kadar özel bir strateji ile yakınlaştıran unsur sadece Rusya ve Çin arasında konumlanması mıdır? Öyleyse tüm bu devletlerin Moğolistan hakkındaki politikalarının sadece komşu birer devlet oldukları için ortaya çıkmadığı anlaşılmaktadır. Jeopolitik teorilerden Kara Hakimiyet Teorisi, Moğolistan'ın içinde bulunduğu alanın önemini açıklayarak bu sorunun cevabını vermektedir. Moğolistan da tam olarak Mackinder'in incelemesinde yer alan bölgede bulunduğu için jeopolitik açıdan günümüzde de önemini korumaktadır. $\mathrm{Bu}$ bağlamda incelendiğinde Moğolistan'ın, Çin ve Rusya'nın yanı sıra ABD'nin de politikasındaki yeri açıklamaya kavuşmaktadır. Mackinder'in açıklamaları değerlendirildiğinde, Avrasya'nın iç bölgelerinin "kalpgah" olarak nitelendirildiği görülmektedir. Dünya’nın büyük kısmı üzerinde yani "dünya adasında" mutlak bir hakimiyet oluşturabilmek için kontrol edilmesi gereken esas alanın, Moğolistan'ın da içinde bulunduğu bu bölgeden oluştuğu belirtilmektedir. $\mathrm{Bu}$ alanların belirtildiği haritalar incelendiğinde Moğolistan'ın kalpgahta bulunduğu görülmektedir. ${ }^{3} \mathrm{Bu}$ bakımdan incelendiğinde Moğolistan'ın uluslararası sistemdeki yerinin önemi jeopolitik ile doğru orantılı olduğu görülmektedir.

Çalışmanın hipotezi temel olarak, Moğolistan'ın 1990 sonrası dış politikasının “küçük devletler" yaklaşımına uygun olarak ABD ile olan ilişkileri bağlamında incelenmesidir. $\mathrm{Bu}$ çalışmada öncelikle Moğolistan ve ABD ilişkilerinin tarihi ve siyasi gelişimi incelenecek, ardından Moğolistan’ın ABD için önemi ve yeri ile ABD’nin Moğolistan için önemi açıklanacak, sonrasında ise Moğolistan ve ABD arasındaki ekonomik ilişkiler incelenecektir.

\section{Moğolistan- Amerika Birleşik Devletleri İlişkilerinin Tarihi ve Siyasi Gelişimi}

\subsection{Moğolistan- Amerika Birleşik Devletleri İliş̧kilerinin Tarihi}

Moğolistan ve ABD arasındaki tarihi geçmiş oldukça yakın zamana dayanmaktadır. Diplomatik ilişkilerin tam manası ile yirminci yüzyılın ikinci yarısında kurulması, tarihi bağlamda ne kadar yeni ilişkiler olduğunu göstermektedir. 1990'ların son evresinde Sovyet Bloğundan ayrılarak kendi dış politika eksenini oluşturmaya başlayan Moğolistan, Amerika Birleşik Devletleri ile de ilişki kurmaya başlamıştır. 
1985 'te Çin-Sovyet gerginliğinin hafifletilmesi ve 1990'da Sovyet bloğunun dağılması Moğolistan'ın 1987'de Amerika Birleşik Devletleri ilişkileri kurmasına izin verdi ve böylece Moğolistan'ın tanıma arayışı hemen hemen tamamlanmış oldu. ${ }^{4}$ ABD'nin Moğolistan'1 tanıması ve diplomatik ilişkiler kurmaya başlaması 1987 kadar yakın bir tarihe dayanması, Rusya ve Çin ilişkilerinden ne kadar yeni olduğunu göstermektedir. İki ülke 27 Ocak 1987 'de Moğolistan Halk Cumhuriyeti'ni ortak bir tebliğde resmi diplomatik ilişkiler kurduğunda kabul etti fakat bundan önce; Amerika Birleşik Devletleri, Kennedy, Johnson, Nixon ve Carter Yönetimi sırasında çeşitli vesilelerle mazeret göstermiştir; Moğolistan temsilcileri ile yapılan iç tartışmalar ve gayrı resmi görüşmeler ile dahi başarı elde edilmemiştir. ${ }^{5}$

Aynı zaman diliminde Moğolistan'ın BM'ye başvurularının 1946 yılından 1987 yılına dek defalarca ABD tarafından veto edilmesi, Moğolistan ve Amerika arasındaki ilişkilerin bu kadar geç yoluna girmesini açıklamaktadır. Buna rağmen ABD’nin İkinci Dünya Savaşı yıllarında dahi Moğolistan'a diplomatik ziyarette bulunması, ikili arasında ileriki döneme ait ilişkilerinin bir sinyali niteliğini taşımaktadır. 1944 yılının Temmuz ayında Başkan Yardımcısı Henry Wallace Ulanbatur'u ziyaret etmiştir. ${ }^{6}$ Sovyetler Birliği'nin etkisi atlında ABD'den tamamen zit bir ideoloji ile hareket eden Moğolistan'a karşı bu tavır Soğuk Savaş'ın son yıllarına kadar devam etmiştir. Sonuç itibari ile Sovyetler Birliği ve Amerika Soğuk Savaş yılları boyunca birbiri ile yarışan iki ayrı ideolojinin liderleri idiler ve Moğolistan da Sovyetler Birliği tarafından idame ettirilen bir doğu bloğu parçasıydı. Soğuk Savaş'ın sona ermesi ve Moğolistan'ın ulusal çıkarları doğrultusunda siyasi bir eksen belirlediği yıllara gelindiğinde, Amerika ile diplomatik ilişkilerini geliştirme, hatta bir ittifak arayışı içerisinde olduğu gözlemlenmektedir. Bu doğrultuda 1987 yılında sonuçlanan diplomatik ilişki kurma çabalarından sonra Moğolistan ve ABD ilişkileri büyük bir hızla gelişip, üçüncü komşu politikasına doğru evirilmiştir.

\section{2. Üçüncü Komşu Politikası}

Tarihi bağlamda yeni olarak nitelendirilebilecek ilişkilere rağmen ABD, Moğolistan için Rusya ve Çin ile eşit bir stratejik öneme sahiptir diyebiliriz. Özellikle siyasi bağlamda, Moğolistan'ın denge politikası doğrultusunda ABD’nin yeri oldukça 
önemlidir. Kurulan denge politikasında Çin ve Rusya'ya bir alternatif olarak denklemde yerini alan ABD, 1990 sonrası Moğolistan dış politikasındaki bir diğer önemli müttefik olarak politikayı tamamlamaktadır. Bunun en önemli göstergesi ABD’nin “Üçüncü Komşu” olarak addedilmesidir. ABD’nin resmi internet sitesindeki deyişle; Rusya ile Çin arasında bulunan Moğolistan, Amerika'yı "en önemli üçüncü komşu" olarak tanımlıyor. ${ }^{7}$ Coğrafi olarak sınır komşusu olmamasına rağmen bir ülkenin komşu olarak nitelendirilmesi, siyasi politikadaki yerini açıkça ortaya koymaktadır. Teorik olarak bakıldığı zaman üçüncü komşu politikası da bir stratejik adımdır ve Moğolistan'ın bu tanımlama içerisine aldığı tek devlet ABD değildir. Bu üçüncü ortak, Amerika Birleşik Devletleri, Japonya, Güney Kore, Almanya ve diğer Batılı ülkelerin yanı sıra Dünya Bankası, IMF ve Asya Kalkınma Bankası gibi uluslararası finansal ve ekonomik kurumlardır. ${ }^{8}$ Üçüncü komşu kavramı, nitelendirilen aktörler bağlamında incelendiğinde; Moğolistan'ın coğrafi olarak sadece iki komşuya sahip olması sonucu geliştirdiği ittifaklara verdiği isim olarak ele alınabilir. Özellikle sahip olduğu iki komşusu sadece bölgede değil, sistemde de büyük güçler olan Rusya ve Çin olduğu için üçüncü komşu politikası gibi bir yaklaşımın Moğolistan dış politikası için stratejik bir adıma dönüşmektedir. Gerek bölgede gerekse uluslararası sistemde siyasi ve ekonomik ortaklıkların yakınlığını tanımlamak için kullanılabilecek bu kavramda, denge politikasına da uygun olacak biçimde; Rusya ve Çin'e bağımlı kalmamak adına oluşturulan üçüncül ilişkiler anlatılmaktadır. Farklı bölgelerden farklı devletler ve çeşitli uluslararası kurumları kapsayan üçüncü komşu kavramındaki stratejik olarak en önemli aktör ABD'dir. Çalışmada da üçüncü komşu bağlamında nitelendirilecek olan devlet ABD'dir. Üçüncü komşu statüsü sağlanan diğer devletlere bakıldığında, küresel bir güç olarak nitelendirilebilecek tek devletin ABD olduğu göz önüne alındığında, Moğolistan dış politikası için en önemli üçüncü komşunun $\mathrm{ABD}$ olduğu da ortaya çıkmaktadır. Siyasi gücün yanı sıra ABD'nin Moğolistan'a etkin ekonomik ve insani yardımları da bu algıyı pekiştirmekte yardımcı olmuştur. Kavramın içeriğine bakıldığında sadece siyasi ve askeri unsurları barındırmamaktadır; ekonomik yardımları, sosyal konularda yapılan yardımları ve projeleri de içermektedir. Buna örnek olarak; 1991'de Moğolistan'a acil enerji yardımı teklif eden ABD, 1990'ların ortalarında acil durum tereyağı ve buğday temin etti ve 1999-2002 yılları arasındaki üç yıl boyunca sert kış afetlerinde acil yardım sağlama 
konusunda çok aktifti. ${ }^{9}$ Örnekteki gıda maddesi yardımı gibi doğrudan doğruya Moğol halkına etki eden konuları içermesi, üçüncü komşu kavramının içeriğinin tüm konuları kapsadığını göstermektedir. Özellikle ABD’nin küresel bir güç olarak, bölgede Çin ve Rusya ile hâkimiyet için çekişmesi göz önünde bulundurularak "üçüncü komşu" kavramı ele alındığında, bu yaklaşımın Moğolistan dış politikası için büyük bir hamle olduğu ortaya çıkmaktadır. Çin ve Rusya'nın da Moğolistan'a aynı şekilde ekonomik ve sosyal meselelerde yardım etmiş ve edebilecek olması; ABD'nin Moğolistan iç ve dış politika konularına müdahil olması ile ilişkileri çekişmeli bir duruma sebebiyet verebilecek hale getirmektedir. Tüm bunlar göz önüne alındığında çalışmada Moğolistan ve ABD arasındaki ilişkiler incelenirken üçüncü komşu politikası bağlamında analiz sağlanacaktır.

ABD küresel bağlamda büyük bir güç olduğu halde, küçük bir devlet olan Moğolistan ile birincil dereceden müttefikliği nasıl gelişmiştir? Coğrafi olarak oldukça uzak bir konumda bulunmasına rağmen, Çin ve Rusya kadar Avrasya'da nasıl böyle bir siyasi ilişki oluşturmuştur? $\mathrm{Bu}$ durum üçüncü komşu politikasına uygun olarak gelişen ilişkiler bağlamında açıklanabilmektedir fakat bölgede bu iki devlet kadar önemli bir yere sahip olmasının sadece üçüncü komşu politikası ile açılanması yeterli olmayacaktır. Üçüncü komşu kavramı kaynaklarda sadece örneklendirilen diplomatik ilişkilerden ve yardımlardan ibaret değildir. Bugün üçüncü komşu politikası zaman içinde değişmiş ve Moğolistan'ın adapte olabilirliğini gösteren bir terim haline gelmiştir. ${ }^{10}$ Adapte olabilirliği kavramı, 1990 sonrası dağılan Sovyetler Birliği’nden ayrı halde uluslararası arenada demokratik bir şekilde var olan ve küresel dünyanın siyasi ve ekonomik gereklilikleri ile stratejik politikalar doğrultusunda ittifaklar kurup, uluslararası kuruluşlar ile uyum içinde hareket eden Moğolistan'1 belirtmektedir. Bu bağlamda ele alındığında Moğolistan'ın Sovyetler Birliği sonrasında bölgedeki en kolay demokratikleşen, ABD ile kuracağı ittifak ile ABD’nin bölgedeki konumunu belirleyecek bir ülke olduğu ortaya çıkmaktadır. Yani üçüncü komşu politikası sadece Moğolistan'ın ABD ile kuracağı barışçıl diplomatik bağları ve talep edilen yardımları içermemektedir. ABD'nin de bu komşuluk ilişkisi olarak addedilen ittifaktan stratejik çıkarları bulunmaktadır. Siyasi olarak demokratikleşip, ekonomik olarak liberalleşen bir Moğolistan'ın ABD’ye yakınlaşması kolaylaşmaktadır. Nihayetinde Sovyet 
etkisinden kurtulup, ABD’ye yakın ilişkiler kurarak; ABD’nin Rusya ve Çin etkisindeki bölgede bir müttefik daha elde etmesini sağlayacaktır. Hem de elde ettiği bu müttefikin jeopolitik yeri, Rusya ve Çin arasında konumlanması başta olması sonucu, oldukça stratejiktir. Bu doğrultuda ABD, Moğolistan'ın siyasi olarak gelişimi için diplomatik ilişkilerinin kurulduğu zamandan bu yana sürekli bir destek unsuru olmuştur. Özellikle demokratikleşmesi adına yapılan diplomatik ziyaretler iki devlet arasındaki ilişkilerin sağlam bir temelde gelişmesine olanak sağlamıştır. ABD’nin Moğolistan'ın genç demokrasisine verdiği güçlü desteğin işareti olarak, demokratik Moğolistan'ın 2005'te ABD Başkanı George W. Bush tarafından ziyaret edilmesi gösterilebilir. ${ }^{11}$ Bush'un ziyaretinin yanı sıra 1991'den itibaren aralarında James Baker'ın da bulunduğu devlet sekreterlerinin ziyaretleri, Moğolistan'ın siyasi olarak kabul gördüğünü ispat etmektedir.

Üçüncü komşu politikası hem ABD hem de Moğolistan için, 1990 sonrası dış politikada önemli bir kavram halini almıştır. Moğolistan ele alındığında, coğrafi uzaklık bir yana; ortak bir tarihi, siyasi geçmişi olmayan bir güç nasıl üçüncü komşu olarak addedilip müttefik olarak kabul edildiği konusu ele alındığında, bu noktada da denge politikası ortaya çıkmaktadır. ABD nasıl Moğolistan ile bölgede güçler olan Çin ve Rusya kadar yakın siyasi bağlara sahip olabildi sorusu nasıl bir cevaba sahiptir? Bunun nedeninden önemlisi, Moğolistan'1n ABD'yi neden üçüncü komşu olarak seçtiği konusudur. En önemli sebep denge politikasıdır; bölgedeki iki güçlü aktöre karşılık küresel olarak kıyaslanabilir ölçüde güçlü tek seçenek ABD’dir. Fakat bunun yanı sıra özellikle ABD'nin üçüncü komşu olarak bir siyasi politikada yer almasının temel sebebi ABD'nin bir hegemon devlet olmasıdır. Hegemon devletler ve onların stratejileri, Moğolistan gibi küçük devletler kategorisine giren devletler tarafından takip edilen devletler olmalarına neden olmaktadır. Amerika Birleşik Devletleri'nin küresel bir hegemon olarak, stratejisi doğrultusunda Moğolistan'a hem uluslararası sistemde hem de bölgede müttefik olmasının başlıca nedeninin hegemon oluşu kabul edildiğinde; hegemon ABD’nin Moğolistan tarafından sistematik davranışlarının takip edileceği teorik olarak ortadadır. Bahsedildiği üzere Moğolistan denge politikası doğrultusunda ABD'yi oldukça yakın müttefiki olarak kabul etmiştir. Bu ittifak ilişkisinde Moğolistan'ın ABD’nin hangi davranışlar çerçevesinde öncül olarak kabul 
ettiği bir başka önemli noktadır. Bir hegemon ve takipçisi arasındaki ilişkilerin biçimini belirleyen belirli stratejiler mevcuttur. Bunlar; yumuşak denge stratejisi, birbirine bağlı düşüş stratejisi, tehdit, katılmama stratejisi, uyum, bağ stratejisi ve tarafsızlık stratejisidir. Bu stratejiler Moğolistan gibi takipçi devletlerin, büyük güçler ile ilişkilerini düzenlemelerinde belirleyici unsurlardır. Sayılan stratejiler devletlerin birbirine yakınlık derecesini tanımlayabilecek şekilde gruplandırılabilir. Buna göre yumuşak denge stratejisi, uyum ve bağ stratejisi güçlü devlet ile yakın ilişkilere sebebiyet verirken; tehdit, katılmama stratejisi ve tarafsızlık stratejisi daha mesafeli ilişkileri ifade etmektedir denilebilir. Moğolistan ve ABD arasındaki ilişkiler incelenirken, özellikle yumuşak denge stratejisinin etkili olduğu yorumu yapılabilir. Yumuşak denge stratejisi, yumuşak güç kavramı ile benzerlik gösteren kavramlar üzerine kuruludur. Diplomasiye dayanan siyasi ilişkiler, uluslararası kurum ve kuruluşlarla desteklenmiş ekonomik ilişkiler ve uluslararası hukuka dayanan anlaşmalar çerçevesinde şekillenen ilişkiler doğrultusunda; Moğolistan'ın dış politikasına uygun bir müttefiklik ilişkisi oluşturan bir stratejidir. Bu noktada ABD'nin gücü ve güvenlik için ortak noktadaki politikalar kabul edilir fakat denge politikası da korunarak tamamen güçlü devletin siyasi hakimiyetine girmek de reddedilir. Her iki devletin de 1990 sonrası dış politikalarında denge, uyum ve barış ortamına yönelik davranışlar temeli bulunduğundan, günümüz ilişkileri için sayılan stratejilerden tehdit stratejisi gibi olumsuz ya da katılmama stratejisi gibi bağlantısız stratejilerin tercih edilmediği görülmektedir. Bunun yerine benimsenen strateji doğrultusunda, ABD'nin öncülüğünü yaparak Moğolistan'ın uluslararası siyasi, ekonomik ve sosyal alanlarda faaliyet gösteren kuruluşlara katılması ve uluslararası sisteme uyum sağlaması konusunda gelişen bir ilişkileri bulunmaktadır. Çalışmanın ilerleyen kısımlarında bahsedileceği üzere, jeopolitik olarak önemli bir yerde bulunan Moğolistan üzerinde etki kurmak isteyen $\mathrm{ABD}$ ve bu etkiyi denge politikası ile birlikte yürüterek sunulan siyasi ve ekonomik ortaklıklardan stratejik olarak yararlanmayı başaran Moğolistan arasında, devletlerin dış politika çıkarlarına uygun adımlar doğrultusunda gelişmekte olan bir ilişki mevcuttur. Siyasi ve askeri açıdan değerlendirildiğinde bu duruma verilebilecek en önemli örnek Birleşmiş Milletler ve NATO’dur. 


\subsection{Moğolistan ve Amerika Birleşik Devletleri Arasındaki Siyasi İlişkilerin Gelişimi}

Moğolistan’ın Birleşmiş Milletler ile temasa geçmesi 1946 y1lına dayanmaktadır. 1961 'de BM üyesi olana dek pek çok defa teklifi geri çevrilmiştir. Bunda ABD’nin gerçekleştirdiği vetolar oldukça etkili olmuştur. Fakat özellikle 1990 sonrası değişen uluslararası denklem sonucunda yakınlaşan ABD ve Moğolistan ilişkilerine paralel olarak, Moğolistan'ın BM ilişkileri de gelişmiştir. ABD’nin Moğolistan'ın demokratikleşmesindeki destek politikalarına benzer faydalar içeren BM üyeliği; Moğolistan'ın 1990 sonrası uluslararası sisteme entegre olması ve güvenlik ile ilgili oluşturduğu dış politikada aynı yönde faydalı olmuştur. 27 Ekim 1961'de tam teşekküllü üyeliğinden bu yana, Moğolistan BM'ye aktif bir üye olarak katılmıştır ve faaliyetleri ile amaçlarına katkıda bulunmuştur. ${ }^{13}$ BM'nin resmi sitesinde yayımlanan raporlar ve konuşmalar incelendiğinde, Moğolistan'1n BM'de uluslararası güvenlik, BM barış gücü operasyonları ve kalkınmakta olan ülkelere özel sosyo-ekonomik hususlarsa etkinlik gösterdiği görülmektedir.

BM Moğolistan'ın ulusal egemenliğini sağlayıp, hem bölgesel hem de uluslararası arenada güvenliğini işbirlikleri aracılığı ile sağlaması açısından oldukça önemli yere sahiptir. Demokrasi Topluluğu'nun da Moğolistan'ın gelişmesi için önemi oldukça büyüktür. Demokrasi Topluluğu, ülkelerin demokrasi olarak gelişmesi için gerekli olan hak ve özgürlükleri tanımlamaktadır. Varşova Deklarasyonu, Demokrasi Topluluğu için yol haritasıdır ve bu belge, 2000 yılında Varşova Deklarasyonu'nu imzaladıklarında 106 ülkenin tanıdığ 1 demokratik ilkelere bağlı olanlar için bir işaret olarak da hizmet etmektedir. ${ }^{14}$ Moğolistan da bu ülkelerden biridir ve güncel olarak incelendiğinde, toplulukta etkinliğinin devam ettiği görülmektedir. Örnek olarak; 2013 yılında Moğolistan, Demokrasiler Topluluğundaki küresel hareketin başarıyla yürütülmesini desteklemek için her yıl 150.000 Amerikan Doları katkı sağlamaya taahhüt vermiştir. ${ }^{15}$ ABD ise Moğolistan'ın Batı'ya yaklaşıp, bu organizasyonlara üye olması açısından önem taşımaktadır. Denilebilir ki Moğolistan'ın demokratikleşmesi ve Sovyetler Birliği’nin etkisinden çıkıp bağımsız bir devlet oluşunda; ABD'nin Moğolistan'ın gelişimi üçüncü komşu politikasına uygun bir biçimde destekleyerek, BM gibi kuruluşlara katılımına etkili olması sonucu ile yön vermiştir. 1990'dan 
itibaren Moğolistan'ın demokratikleşmesinde ve güvenlik konularında yardımcı olan BM ile ilişkileri, güncel olarak devam etmektedir.

Moğolistan'ın bölgede ve uluslararası sistemdeki birincil endişesinin güvenlik olduğu göz önünde bulundurulursa, NATO'nun amaç itibari ile neden örnek olduğu açıklanabilir. Küçük devletler için uluslararası güvenlik kuruluşları tarafından güvence altında olmak, güvenlik endişelerini büyük ölçüde azaltabilecek bir adımdır. Moğolistan için hem bölgedeki komşuları için hem de uluslararası sistemdeki yeri için duyduğu güvenlik endişesi için NATO gibi bir kuruluşun önemi ortadadır. Şuan itibari ile Moğolistan NATO’nun bir üyesi değildir ancak aktif ortaklıkları ve işbirlikleri bulunmaktadır. 1990ların sonundan itibaren uluslararası sisteme adapte olabilmek için sistemdeki aktörlerle ilişkilerini geliştiren Moğolistan'ın NATO ile 2005 yılından bu yana işbirliğine dayanan, barış amaçlı operasyonlarda rol alarak ilerlettiği bir ilişkisi bulunmaktadır. Moğolistan ve NATO, barış, demokrasi, insan hakları, hukukun üstünlüğg̈ ve uluslararası güvenliğe ilişkin ortak bir taahhüde dayanarak Mart 2012'de birlikte çalışabilirliği artırmak, küresel güvenlik konularını ele alan planlar geliştirmek için; kriz önleme ve yönetimi için mekanizmalar ve kapasite geliştirmeden yola çıkan bir "Bireysel Ortaklık ve İşbirliği Programı" (IPCP) kabul ettiler. ${ }^{16}$ Güncel olarak da destek operasyonlarında yer almaktadır. NATO'nun resmi verileri incelendiğinde, Moğolistan'ın 2005- 2007 y1lları arasında Kosova Gücü’ne, 2010'da Afganistan'daki Uluslararası Güvenlik Yardım Gücü'nde, Ağustos 2014'ten bu yana ise NATO’nun Ortaklık Eğitim ve Eğitim Merkezleri ağı kapsamında Moğolistan'daki eğitim merkezi ile yer aldığı görülmektedir. Bu katılımlar ve işbirlikleri Moğolistan'ın NATO hedefi için stratejik adımlar attı̆̆ını göstermektedir. ABD, NATO ve Moğolistan'ın stratejik planlarının ortak noktasına bakıldığında ise, Moğolistan'ın jeopolitik konumunun önemi yine ortaya çıkmaktadır. Moğolistan ABD Pasifik Komutanlığı'nın sorumluluk alanına aittir; bu nedenle Washington, Pekin'e, Seul'e ve Tokyo'ya coğrafi yakınlığı sayesinde Orta Asya ile ilişkilendirmek yerine Ulaanbaatar'ın Kuzeydoğu Asya ile entegre olma arzusunu desteklemekle daha fazla ilgilidir. ${ }^{17}$ ABD'nin Kuzeydoğu Asya'daki planları için bir adım noktası oluşturan Moğolistan'ın yeri ve NATO'ya katılımı, NATO aracılığı ile askeri ve siyasi olarak ABD'nin planlarını desteklemektedir. Söz konusu işbirliklerinin geliştirilip, kalıcı bir üye olması için de 
ABD’nin yönlendirmeleri oldukça gereklidir. Üçüncü Komşu Politikası kapsamında, Batı'daki en güçlü komşusu ve müttefiki ABD olduğu için, bu süreçte ABD'nin desteği Moğolistan için stratejik öneme sahiptir. Bu bakımdan ABD ve Moğolistan arasındaki siyasi ilişkiler, Moğolistan'ın uluslararası kuruluşlara entegre olma aşamasında yardımcı bir ortaklıktır.

Moğolistan ve ABD arasındaki güncel siyasi ilişkilerin de mevcut stratejiler doğrultusunda ilerlediği görülmektedir. Bu doğrultuda iki ülke arasındaki işbirliğinin gelişmesi adına, 2004 yılının temmuz ayında Moğolistan ve Amerika Birleşik Devletleri Arasında Ortak Beyan deklarasyonu önemli bir adım olarak karşımıza çıkmaktadır. Bush ve Baganabdi döneminde imzalanan anlaşma, ikili arasındaki ortaklığı desteklemesinin yanı sıra; ABD’nin Moğolistan'ın demokratikleşme ve küreselleşme sürecini tanıyıp desteklemesi açısından da önem taşımaktadır. Başkan Bush, Birleşik Devletlerin Moğolistan'ın demokratik ve ekonomik geçiş ve reformlarına verdiği güçlü desteği dile getirdi ve Moğolistan'ın olgun ve istikrarlı demokrasi ve özel sektör liderliğindeki serbest piyasa ekonomisi olma yolundaki ilerlemesini memnuniyetle karşıladı. ${ }^{18} \mathrm{Bu}$ anlaşma, ABD'nin Moğolistan'ı hem siyasi hem de ekonomik bağlamda destekleyerek, müttefiki olarak gelişmesi yönünde etkilediğini gösteren bir anlaşmadır. Moğolistan'ın serbest piyasa ekonomisinde gelişme çabaları, 1990larla birlikte dağılan Sovyet Bloğundan ayrılması ve ABD’ye yakınlaşması bakımından Batı dünyasına, dolayısıyla küresel siyasete ve küresel ekonomiye yaklaştığını göstermektedir.

İki devlet arasında imzalanan deklarasyonlar incelendiğinde, güncel anlaşmalar halen yumuşak denge stratejisinin prensipleri çerçevesinde oluşturulmakta olduğu görülmektedir. 2007 yılında imzalanan Amerika Birleşik Devletleri ve Moğolistan Arasındaki İşbirliği İçin İlkelerin Beyanı belgesindeki içerik bunu açıkça ortaya koymaktadır. Resmi belgenin sayılı numaralardaki ilkeleri incelendiğinde:

1. İnsan hakları, hukukun üstünlüğü ve şeffaflık gibi demokratik değerlere bağl1lıklarıyla karakterize edilen güçlü demokrasiler ve canlı bir özel sektörün öncülük ettiği sağlam piyasa ekonomileri en iyi ortak yapar; 
2. Güçlü bir ticaret ilişkisi kurmak ikili ilişkilerin genişlemesi açısından önemlidir ve açık bir yatırım ortamı sağlanması ve ticarette ve yatırımda engellerin azaltılmasına ve ortadan kaldırılmasına yönelik önlemler bu sürecin anahtarıdır,

3. İkili ve çok taraflı güvenlik ve istikrar faaliyetlerine katılım, küresel barışı koruma operasyonlarında ve insani yardımların başarılı bir şekilde uygulanmasında ve afet yardımı faaliyetlerinin yürütülmesinde personelin ve ekipmanın birlikte çalışabilirliği için bir anahtardir.

7. Barış, adalet ve refahı geliştirmek için ortak çıkarlara dayanan Amerika Birleşik Devletleri ile Moğolistan arasında kapsamlı ve eşit bir ortaklık hem uluslara hem de bölgeye fayda sağlamaktır. ${ }^{19}$

Maddeleri, iki ülkenin de ilişkilerini oluştururken uyguladığı stratejilerin bir özeti niteliğindedir. Hem siyasi hem de ekonomik anlaşmaların temelini oluşturan; uluslararası hukuk kuralları, güvenlik olgusu ile uluslararası sistemde ve bölgede müttefiklik olgusunu kanıtlar nitelikte bir deklarasyondur.

İki devlet arasındaki ilişkilerin temelini örnekleyebilecek bir diğer resmi veri ABD Dışişleri Bakanı Hillary Clinton'un 9 Temmuz 2012'de Moğolistan'da Uluslararası Kadın Liderliği Forumu'nda yaptı̆̆ı konuşmadır. Bu konuşmada Moğolistan'a on yedi yıl önce yapmış olduğu ziyaretten de bahsederek, Moğolistan'ın geçirdiği demokratikleşme sürecinin başarısı, seçim sisteminin başarıyla işlemesi, parlamentonun seçilen yeni kadın üyeleri konuları hakkında konuşmuştur. Moğolistan'ın siyasi başarısından bahsederken; Moğolistan'ın geleceği hakkında kendi düşünceleri olan güçlü komşularla çevrili olan Moğol halkı, tek partili bir Komünist diktatörlüğünden çoğulcu, demokratik bir siyasi sistem haline getirme cesareti ile bir araya gelmiştir demiştir. ${ }^{20}$ Konuşmada belirtilen demokratik gelişme sürecinin $\mathrm{ABD}$ tarafından desteklendiğinin görülmesi, Moğolistan'ın uluslararası sisteme dahil olma hedefinin gerçekleştiğini kanıtlayan örneklerden biridir.

Moğolistan tarafından ABD'ye gerçekleştirilen diplomatik ziyaretler aracığı ile de ilişkilerin düzenli ve sağlam bir zemine yayıldığı görülmektedir. Güncel diplomatik ziyaretlerin içeriğine dair Elbegdorj 'un 2011 yılında yaptığı ziyaret örnek olarak incelenebilir. Görüşme sonrasında imzalanan karar, iki devlet arasındaki ilişkilerin 
güncel olarak da aynı çizgide ilerlediğini belirtmektedir. Karar incelendiğinde özetle şu maddelere ulaşılmaktadır:

1. Moğolistan Devlet Başkanı Tsakhiagiin Elbegdorj 'un Washington'a yaptığı ziyaret, hükümetler ile Birleşik Devletler ve Moğolistan halkları arasındaki artan dostluğu ortaya koymaktadır.

2. Demokratik reformların ilerletilmesi ve yatırımın korunması için Moğolistan halkının ve Moğolistan hükümetinin devam eden taahhüdü kabul etmelidir.

3. ABD hükümeti, Moğolistan'la ekonomik, akademik ve kültürel işbirliğini teşvik etmeye ve Moğolistan için uluslararası mali yardımı desteklemeye devam etmelidir. ${ }^{21}$

Güncel siyasi ilişkilerin boyutunu ortaya koyan bu diplomatik ziyaret ve sonucunda alınan karar, Moğolistan ve ABD arasındaki devam eden siyasi ilişkinin demokratikleşme ve Amerika'nın devam etmekte olan desteğini gösteren bir örnektir. Ayrıca Moğolistan'a yapılan yatırımların devamlılığını desteklediğini açıkça göstermektedir.

Bunun yanı sıra iki devlet arasında farklı ekonomik anlaşmalar ve uluslararası kuruluşlara katılım ve buradaki işbirliklerinin sürdürülmesine yönelik sayılanlara benzer birçok anlaşma bulunmaktadır ve onlar da aynı temel ilkeler doğrultusunda oluşturulmuşlardır. İleriki kısımlarda bahsedilecek olan ticari anlaşmalar, ekonomik ve insani yardım anlaşmaları ve uluslararası organizasyonlara yönelik anlaşmalar ile iki devlet arasındaki ilişkinin temeli ve koşulları daha ayrıntılı olarak yorumlanacaktır. Fakat iki devlet arasındaki diplomatik adımların temeli, verilen örnekler doğrultusunda, güvenlik tabanında karşılıklı ulusal çıkarların sağlanması ile geliştirilen karşılıklı işbirliğidir denilebilir. Moğolistan'ın denge politikasını gözeterek oluşturduğu bu ittifak, çalışmanın dayanak noktalarından biri olan küçük devletler yaklaşımına uygun olarak; güçlü devletlerin gücünü, ulusal çıkarları ve güvenliği, hem bölgede hem de uluslararası sistemde sağlayabilmesi adına ABD’nin önemini ortaya koymaktadır. ABD için de oldukça önemli bir bölge olan Avrasya'da yakın bir ortak edinmek sayılan unsurlar için önemli olduğu kadar jeopolitik meselesinin önemini de ortaya çıkarmaktadır. Diğer ülkeler ele alınırken olduğu gibi, ABD ile olan ilişkilerin 
incelenmesinde de jeopolitik bir inceleme yapmak iki devlet arasındaki ortaklığ tanımlamak adına açıklayıcı olacaktır.

\section{Moğolistan'ın ABD İçin Önemi ve Yeri \& ABD'nin Moğolistan İçin Önemi}

ABD için Moğolistan'ın başlıca önem teşkil ettiği konu jeopolitik yeri ve jeostratejik önemidir. ABD için Moğolistan'ın jeopolitik konumu aynı sebepler ile önemlidir. Avrasya'nın hem Kara Hakimiyet Teorisi doğrultusunda hem de ABD’nin Soğuk Savaş'ın hemen bitiminde elde ettiği tek başına süper güç olma durumu sonucunda, Avrasya'ya hükmetme politikaları doğrultusunda jeopolitik önemi anlaşılmaktadır. Bunun yanı sıra 1990'ların başında, Sovyetler Birliği'nin dağılması sonucu eş değer rakibinin ardından tek başına küresel bir güç konumuna gelen ABD için Avrasya; Sovyetler Birliği'nin etkisinden kurtulan bölgeye hükmetmek için oldukça önem arz etmekteydi. Moğolistan'ın, ABD için küresel boyutta önemsenmesi gereken iki büyük güç olan Rusya ve Çin arasında konumlanmış olması öncelikli jeopolitik hedef olmasına neden olmaktadır. Amerika Birleşik Devletleri için Avrasya stratejisi, jeostratejik açıdan dinamik devletlerin amaca yönelik yönetimini ve jeopolitik olarak

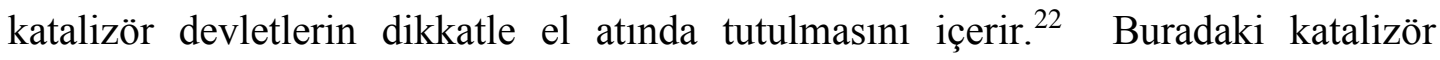
devletlerden en stratejik noktada konumlanmış olanının Moğolistan olduğu söylenebilmektedir. $\mathrm{ABD}$ açısından tek bir devlet ile kurulacak yakın diplomatik ilişkilerin, hem Rusya'yı hem Çin'i bu denli yakından takip etmesine olanak veren tek devletin Moğolistan olduğu görülmektedir. Moğolistan'ın bu konuda tek olarak nitelendirilmesindeki neden jeopolitik yeridir. Bölgede ABD ile yakın diplomatik ilişkiler içerisinde bulunan tek ülke Moğolistan olmamakla birlikte, gerek coğrafi konumu gerekse ortak ekonomik projeler ile bu önemli güçler arasında aktif bir köprü olarak yer alması, özel bir yere sahip olmasına neden olmaktadır.

ABD’nin Avrasya'daki politikası 1990'dan günümüze kadar temel hedefte aynı doğrultuda ilerlese de, zaman içinde farklılık göstermiştir. 1990'a kadar Soğuk Savaş süresince Sovyetler Birliği’nin komünist bloğuna karşıllı olarak kapitalist blok olarak yer alan ABD, Sovyetler Birliği'nin dağılması sonucu uluslararası sistemdeki güçler arasında konumu ve potansiyeli itibariyle tek büyük güç olarak nitelendirilmiştir. Bazı açılardan, Amerika Birleşik Devletleri ve Sovyetler Birliği arasındaki çekişme 
jeopolitik uzmanlarının en sevdikleri teorinin gerçekleştirilmesini temsil ediyordu: Hem Atlantik hem de Pasifik Okyanusu'nda egemen olan, dünyanın en önemli deniz kuvvetleri, (Moğol İmparatorluğu'nun kapladığı toprakları hatırlatan) Avrasya'nın merkezi topraklarında hüküm süren dünyanın en önemli kara kuvvetlerine karşı yarışıyordu. ${ }^{23}$ En büyük çekişme de Sovyetler Birliği’nin en çok güvendiği ve hakim olduğu alan olan Avrasya bölgesinde yaşanıyordu. Fakat bu çekişmenin sonunda Sovyetler Birliği’nin dağılması, ABD’yi rakipsiz bırakarak, Avrasya politikasına daha fazla yoğunluk vermesine olanak tanımıştır. Moğolistan'ın da bu bölgede bulunması sonucu, oluşturulan politik denklemde büyük güçlerle birlikte yer almasını sağlamıştır.

Soğuk Savaş süreci göstermiştir ki, savaşmak sadece askeri güç ile sağlanan bir fiil değil; ideolojik, ekonomik, siyasi ve kültürel olarak üstünlük elde etme çabasını da ifade etmektedir. Yumuşak güç olarak nitelendirilen unsurlar da söz konusu bölgeyi etki altına almak amacına dahildir. Uluslararası sistemde komünist bloğu geçerek, Moğolistan'ın da içinde bulunduğu hakimiyet alanlarında egemen güç olma niyeti ile atılan adımlar temel olarak bu güç türüne aittir. ABD de bu doğrultuda hareket ederek, Moğolistan'1 jeopolitik bağlamda gerekli bir müttefik olarak görerek, Moğolistan ile olan dış politikasını belirlemiştir. 1990'ların başında Sovyetler Birliği’nin siyasi etkisinden çıkan Moğolistan'ın uluslararası sisteme uyum sağlayıp, demokratikleşmesini tamamlayarak, siyasi ve ekonomik açıdan küresel politikaya uyumlu bir dış politika yapması gerekmekteydi. ABD bu noktada Moğolistan'ın hem üçüncü komşusu olarak, hem de IMF gibi uluslararası kuruluşlara katılımında aktif rol oynayarak, Moğolistan'ın geçiş sürecinde yakın bir ittifak sağlamıştır.

1990'ların başında Amerikan hegemonyası küresel olarak rakipsiz görünmekteydi. Soğuk Savaş’ın bitiminden hemen sonra rakipsiz kalan ABD'nin tek güç olma durumu uzun yıllar devam etmemiştir.1990 sonrasında Çin ve tekrar toparlanan Rusya özellikle Avrasya'da ve konu itibariyle Moğolistan'da tekrar etkili olmaya başlayarak, ABD’ye rakip güçler olacak davranışlar sergilemeye başlamışlardır. Rusya'nın Putin dönemi ile Avrasya politikalarına dönüş yapması Moğolistan ile olan politikasını daha öncelikli hale getirerek ABD’ye tekrar siyasi bir rakip olmuştur. Çin'in ise son yıllarda ekonomik açıdan yükselişe geçmesi; Moğolistan ile yumuşak güç uygulama bağlamında ekonomik ve diplomatik ilişkilerini yoğunlaştırması, Çin'i de ABD için 
önemli bir rakip haline getirmiştir. Soğuk Savaş’ın hemen ardındaki yılların aksine, ABD Moğolistan ile yakın bir müttefik olmasına karşılık, bölgedeki tek etkili güç değildir. Brezinski 'nin görüşleri bu durumu kanıtlar niteliktedir:

“Bu yeni gerçekliğin pratik kabulü, 2008 yılında Asya, Afrika ve Latin Amerika'dan yeni ülkelerin şimdiye kadar Batılı finansal karar alıcıların kulübü olagelmiş G-8'e girişiyle, bu çemberin temsiliyeti daha geniş olan G-20'ye dönüşmesiyle gerçekleşmiştir. Bu değişimin sembolik yansımalarından biri de ABD'de 2009 yılında gerçekleşen ilk G-20 toplantısında en önemli liderlik rollerinin iki devletin başkanları tarafından oynanmasıydı: Bunlar sırasıyla Amerika Birleşik Devletleri ve Çin Halk Cumhuriyeti’ydi."24

\section{Moğolistan ve ABD Arasındaki Ekonomik İlişkiler}

Diplomatik ilişkilerde olduğu gibi ekonomik ilişkilerde de geç yapılan başlangıçlar sonucu, Moğolistan ve ABD arasındaki ekonomik ilişkilerin temeli uzun yıllara dayanmamaktadır. Buna rağmen iki devlet arasındaki ekonomik ilişkiler yapılan yardımlara, bağışlara ve ülke haklını doğrudan ilgilendiren projelere dayalı oluşturulduğundan, Rusya ve Çin ile rekabet edecek bir nitelik kazanmıştır.

Moğolistan'la kurulacak ilişkiler, ekonomik ilişkiler ile desteklenerek bölgede etkili ve stratejik bir ortak edinilmesi açısından $\mathrm{ABD}$ için önem teşkil etmektedir. $\mathrm{Bu}$ bölümde gerçekleştirilen projeler, yatırımlar ve yapılan yardımlar incelenerek, Moğolistan ve ABD arasındaki ekonomik ilişkilerin ikili arasındaki siyasi ilişkilere etkisi açıklanacaktır. Aynı zamanda ekonomik unsurların Moğolistan'ın bölgede ve uluslararası sistemde ABD ittifakı elde etmesine ve ABD'nin bölgedeki stratejik amaçları için ülkeye olan ihtiyacı incelenecektir.

\section{1. İki Devlet Arasındaki Ekonomik İlişkilerin Özellikleri}

Moğolistan'ın ekonomik özellikleri incelendiğinde, 1990'dan itibaren siyasi hayatında olduğu gibi ekonomik hayatında da değişimlerin ve modernleşmenin olduğu görülmektedir. 1990 öncesinde Sovyetler Birliği'nin siyasi ve ekonomik uzantısı olarak adeta bir uydu devlet olarak varlığını sürdüren Moğolistan, bağımsızlık evresinden sonra ekonomik olarak da tamamen yeni bir sürece girmiştir. Siyasi olarak demokratikleşmesi ile doğru orantılı olarak liberal bir ekonomiye geçip, sonrasında 
serbest piyasa ekonomisini benimsemiştir. Uluslararası sisteme uyum sağlaması açısından oldukça stratejik bir adım olarak, önceki bölümlerde de bahsedilen önemli uluslararası projeler ve yatırımlar ile ekonomik bağlarını çeşitlendirmiştir. ABD ve Moğolistan arasındaki ekonomik ilişkilerin özellikleri temel olarak üç unsur etrafında şekillenmektedir. Bu unsurlar; siyasi konularda olduğu gibi ekonomik konularda da uluslararası arenada ABD'nin Moğolistan'ı desteklemesi, ekonomik yatırımlar ve projeler, ABD’nin Moğolistan'a sapladığı ekonomik ve sosyal içerikli yardımlardır.

Gelişen bir demokrasi ve uluslararası sisteme yeni entegre olan bir devlet olduğu için Moğolistan yabancı yatırımları ve ekonomik işletmelere yönelik yabancı desteklere büyük ölçüde izin veren bir devlettir. Kazanç bazında ele alındığında avantajlı görünen bu davranış, uzun vadede halka endişe verici görünmektedir. Önceki bölümlerde de ele alınan yabancı yatırımlara karşı olan endişeli tutum, diğer güçlerde olduğu gibi ABD için de değerlendirilmesi gereken bir konudur. ABD, Moğolistan'a 1990 sonrası dönemde siyasi ilişkiler bölümünde verilen örneklerde görüldügü üzere destekleyici bir müttefik olmuştur. Fakat Moğolistan gibi küçük devletlerde görülen, siyasi olarak denge kurmaya çalışırken, siyasi açıdan müttefiki olunan devlete etkili görünmek amacı ile ekonomik kazancın kullanılması durumu, stratejik kararlar ile düzenlenmesi gereken bir durumdur. Ekim 2009'da Moğolistan, dünyanın en büyük kullanılmayan bakır-altın yatakları arasında Oyu Tolgoi madeni için yatırımları kabul etmiştir ancak Oyu Tolgoi’yi geliştiren yatırımcılar ile ortaya çıkan anlaşmazlık, Moğolistan'ın yabancı yatırım için çekiciliğinin sorgulamasına neden olmuştur. Bunun sonucunda ise doğrudan yabancı yatırımda şiddetli bir düşüşe, ekonominin yavaşlamasına ve Kasım 2014'te Başbakan Altankhuyang'ın görevden alınmasına neden olmuştur. ${ }^{25}$ Örnekte görüldüğü üzere, yabancı yatırımlar aracılığı ile gerçekleştirilen yatırımların küçük devletler üzerinde etkisi birden fazla alanda ortaya çıkmaktadır. Ekonomik adımların ortaya çıkabilecek olumsuz sonuçları, büyük güçlerde orta ölçekli bir kriz iken, Moğolistan gibi küçük güçlerde daha şiddetli etkilere yol açmaktadır. ABD ile olan ilişkilerinde de, Moğolistan'ın siyasi gelişimini ve demokratikleşmesini destekleyen bir ABD ve buna karşılık olarak hem stratejik yeri ile hem de ekonomik kaynakları ile ABD’ye bağlanan bir Moğolistan olmamalıdır. Sonuç olarak Çin ve Rusya'ya alternatif bir üçüncü komşu politikası ile denge sağlamayı hedefleyen bir 
Moğolistan ve ABD ilişki çerçevesi korunmalıdır. Bu bağlamda ABD’nin hâlihazırda Moğolistan için siyasi ve ekonomik yönde gelişimine verdiği destek, stratejik şekilde Moğolistan'ın ulusal çıkarları kapsamında kullanılmalıdır. Bunun için Moğolistan'ın ABD'den alacağı destek ile devam ettireceği hem ekonomik hem de siyasi reform politikaları önem taşımaktadır. Gelişimine destek olan bir gücün onayı ile bunu sadece devletin uluslararası arenada kabul görmesi için değil, halkını da geliştirerek tabandan gelen bir gelişim haline getirmesi gerekmektedir. Yakın gelecekte Moğolistan'ın önemli maden zenginliğinin şeffaf ve kapsayıcı şekilde yönetilmesi gerekmektedir ve böylece elde edilen fayda adil şekilde tüm nüfusa tahakkuk edecektir; yoksulluğun ortadan kaldırılmasının sağlıklı bir demokrasi için vazgeçilmez olduğu göz önüne alındığında, Moğolistan hükümeti için bu önemli bir ilke olmalıdır. ${ }^{26}$ Küçük devletlerin bunun gibi gelişimleri için, daha büyük güçlerden destek aldıkları sürece uluslararası sistemde daha başarılı oldukları göz önüne alındığında, Moğolistan'ın böyle stratejik davranışları devlet davranışı olarak benimsemesi aşamasında ABD ile yakın ilişskiler içinde olması oldukça önemli bir avantajdır. Bu bağlamda ABD ve Moğolistan'ın ekonomik ilişkileri yalnızca yatırım bazında değil, destek ve yol gösterme olgularını da barındırmaktadır.

İki devlet arasındaki ekonomik ilişkilerin sosyal özellikleri de mevcuttur. ABD'nin Moğolistan'a yaptığı ekonomik ve sosyal yardımlar, ikili arasındaki ilişkilerin gelişmesine oldukça yardımcı olmuştur. Devlet kurumları ve sosyal yardım kuruluşları aracılığı ile yapılan yardımlar Moğolistan'a hem ekonomik kalkınması ve yatırım projelerinin gelişmesi hususunda hem de haklın ihtiyaç duyduğu alanlarda yardım sağlaması bakımından fayda sağlamaktadır. İleriki bölümde ayrıntılı olarak bahsedilecek olan ekonomik yardımların miktarı, ABD ve Moğolistan arasındaki ekonomik ilişkilerde önemli rol oynamaktadır. Örnek verilmesi gerekirse, Moğolistan'da ilk yardım programını, ülkenin santrallerine acil ihtiyaç malzemeleri ve yedek parçalar sağlamak için 1991'de başlatan USAID; 1998'de Moğolistan'ın önemli enerji sektörünü güçlendirmek ve sürdürmek için ilave 50 milyon dolarlık malzeme, donanım ve teknik yardım sağlamıştır. ${ }^{27}$ Moğolistan'ın ekonomik kalkınmasını sağlaması adına bu yardımlar önemli meblağları temsil etmektedirler. ABD'nin Moğolistan'a üçüncü komşu olarak sadece demokratikleşme söylemleri ile değil, 
ekonomik kalkınmasına yardımcı olacak yardımlar ile destek olduğu görülmektedir. İki devlet arasındaki ekonomik ilişkilerin bir diğer önemli özelliğinin de ekonomik yardım olduğu ortaya çıkmaktadır.

Moğolistan'ın ekonomik ilişkileri incelendiğinde, ihracat ve ithalat oranları karşılaştırıldığında birinci sırada Çin'in olduğu görülmektedir. ABD’nin üçüncü komşu politikası uyarınca Moğolistan ile olan ilişkileri oldukça yakın olup, diğer komşuları olan Çin ve Rusya ile eşdeğer oranda ilerleme kaydetse de ekonomik ilişkiler bağlamında aynı yerde olamadığı görülmektedir. Moğolistan'ın genel ekonomik yatırımları madencilik üzerine olduğu gibi, ABD ile olan yatırımlarda da madencilik sektörü öne çıkmaktadır.

Moğolistan Ekonomik Kalkınma Bakanlığı'na göre ABD, 2012 yılı itibarıyla sekizinci en büyük doğrudan yatırımcıydı; ABD'nin doğrudan yatırımları, ağırlıklı olarak madencilik (\%38) ile toptan ve perakende ticaret ile yoğunlaşan 292 milyon ABD doları seviyesine ulaşmıştır. ${ }^{28}$ Moğolistan ve ABD arasındaki ticari rakamlar ABD Ticaret Temsilciliği Ofisi’nin resmi açıklamalarına göre incelendiğinde ise: Moğolistan'ın 2016 y1lı verilerine göre, toplam 56 milyon dolarlık ihracat ve 11 milyon dolarlık ithalat ile ABD'nin 1756 milyon dolarlık toplam iki yönlü ticaretle, 175 'inci en büyük mal ticaret ortağı olduğu görülmektedir. ${ }^{29}$ Yine ABD Ticaret Temsilciliği Ofisi'nin resmi verilerine göre, Moğolistan, Amerika Birleşik Devletleri'nin 2016'da 161'inci en büyük mal ihracat pazarı olduğu görülmektedir. Bu sıralamalar göstermektedir ki, ABD ve Moğolistan arasındaki ticari ilişkiler Çin ve Rusya ile olduğu kadar yakın değildir. Buna sebep olarak Moğolistan'ın coğrafi uzaklığı gösterilebilir. Her ne kadar ABD ve Moğolistan üçüncü komşu politikası ile coğrafi uzaklıklara rağmen birbirlerini komşu devletler statüsünde kabul etseler de, coğrafi olarak komşu iki devlet gibi ekonomik ilişkilerde birbirlerine bağımlı değillerdir.

Ticari ortaklıkta birinciliğin diğer güçlerce sahiplenilmesi, ABD’yi ekonomik bağlamda farklı projelere yönlendirmiştir. Alternatif ekonomik bağlar ile Moğolistan ile olan siyasi ilişkilerindeki başarıyı, ekonomik alanda da canlı tutmayı hedefleyen $\mathrm{ABD}$; ithalat ihracat alanındaki eksikliğini ekonomik ve sosyal yardımlar ile 
dengelemektedir. ABD’ye ait devlet kurumlarının uyguladığı programlar, Moğolistan'a mevcut politikalar kapsamında destek sağlamak adına önemlidir. USAID, Doğu- Batı Merkezi ( East West Center) gibi kurumların uyguladığı programlar, eğitim, sağlık, sosyal ve ekonomik alanlarda yaptıkları yardım kampanyaları, bağışlar ve destekler; ABD’nin Moğolistan için oluşturduğu sosyoekonomik stratejiyi tamamlayan unsurlardır. Sivil toplum kuruluşları, ABD’nin hem ekonomik yardımlar yapmasını hem de yumuşak gücünün bir göstergesi olarak bölgede kabul görmesini sağlamaktadır. Bu bağlamda ABD’nin USAID aracılığı ile yapacağı destekler, hem para yardımı olarak ekonomiye katkı sağlayacak; hem de alt yap1 ve eğitim alanlarında gelişerek madencilik sektöründen en yüksek verimi elde etmesini sağlayacaktır. USAID'in yayımladığı 2017 resmi raporu incelendiğinde, Moğolistan'ın ekonomik istihdamını destekleyici programlar uyguladığı görülmektedir. USAID, geçtiğimiz y1l 20 küçük işletmenin rekabet edebilirliklerini geliştirmesine ve satış çeşitliliğini ve istihdamı destekleyerek 2 milyon dolarlık satış yapmasına yardımcı olurken; önümüzdeki iki yıl içinde, daha küçük ve orta ölçekli işletmelerin finansal okuryazarlığını güçlendirecek, bunları kredi ortaklarına bağlayacak ve yaklaşık 25 milyon dolarlık kredilere erişmelerini sağlayacaktır. ${ }^{30}$ Örnekte de bahsedildiği üzere, yapılan yardımlar finansal eğitimleri kapsayacak şekilde, Moğolistan'ın ekonomik gelişimini uluslararası standartlara uyumlu olarak gerçekleşmektedir. $\mathrm{Bu}$ sayede Moğolistan 1990lar ile başladı̆̆ demokratikleşme ve modernleşme sürecini, ekonomik bağlamda da devlet politikasına entegre etmeyi hedeflemektedir.

Gelişmiş bir sanayi ve hizmet sektörü Moğolistan'1n madencilikten sağlayacağı yararı, yabancı yatırımlara bağlı kalmaksızın arttıracaktır. Bu sayede siyasi olarak uluslararası sistemde bağımsız bir aktör olma hedefi, ekonomik bağlamda da gerçekleşmiş olacaktır. Tüm bu stratejik hedeflerin gerçekleşmesi adına, ABD’den USAID gibi kurumların aracılığı ile sağlanan yardım programlarının önemi büyüktür. Siyasi açıdan olduğu gibi ekonomik politikada da Çin ve Rusya'ya alternatif bir üçüncü ittifak olarak ABD ve sağladığı destek Moğolistan için oldukça faydalı olmaktadır. 


\section{Sonuç}

İki devlet arasındaki siyasi ve iktisadi yakın geçmiş ile güncel ilişkileri, Moğolistan'ın dış politikasında ABD’nin önemli bir yere sahip olduğunu göstermektedir. Özellikle Moğolistan'ın dış politika davranışı olarak ortaya koyduğu denge politikasında ABD, Çin ve Rusya karşısında oldukça güçlü bir taraf oluşturmaktadır. Bu bağlamda Moğolistan'ın bölgesel güvenlik endişelerinin ortadan kaldırılmasında oldukça etkili olan ABD; Moğolistan'ın uluslararası sistemdeki güvenliği için de önemli bir aktör olarak karşımıza çıkmaktadır. Moğolistan'ın Soğuk Savaş sonrası oluşturduğu dış politikada öne çıkan en önemli unsurun güvenlik ve stratejik ulusal çıkarları olması, iki devlet arasındaki ittifakın güncel ilişkilerde de sürekli olacağını göstermektedir. Rusya ve Çin'e karşı hem siyasi hem de ekonomik konularda büyük bir güç olan ABD tarafından desteklenerek, yakın ilişkilere sahip olmak Moğolistan dış politikasının hedeflendiği doğrultuda devamlılığg için önem arz etmektedir.

ABD’nin Moğolistan'ın demokratikleşmesi için verdiği siyasi ve ekonomik destekler, Moğolistan'ın diş politika hedeflerine ulaşmasında oldukça etkilidir. ABD Moğolistan'ın dış politikasına dair aldığı kararları destekleyip, uluslararası sistemde güçlü bir müttefik olmasının yanı sıra; çeşitli kuruluşlar ve yardım programları ile Moğolistan'ın hedeflediği değişimi tabana yayarak kalıcı olmasına yardımcı olmaktadır. Moğolistan'ın diğer ilişkilerinde de ekonomik ve siyasi gelişimi için yapılan anlaşmalar ve ticari ortaklıklar yardımeı olmaktadır. Fakat ABD hem devlet destekli hem de sivil toplum kuruluşları aracılığı ile verdiği eğitimler, seçim süreçlerindeki açıklamaları ve demokratikleşmeyi desteklemesi adına kampanyalara yaptığı yardımlar gibi farklarla öne çıkmaktadır. Rusya ve Çin'in de ekonomik açıdan oldukça büyük katkılarının olmasına rağmen; ABD sadece ekonomik kazanca yönelik değil, sistemdeki eksiklikleri kapatıp, sürdürülebilir bir kalkınmayı gerçekleştirebilmek adına desteklerde bulunmaktadır. Yabancı yatırımlar olmadan da ileriki süreçlerde ekonomik sistemde Moğolistan'a yardımcı olabilecek sistemsel gelişmeleri destekleyen ABD, diğer ortaklılardan farklı olarak sorunun tabanına inmektedir. Moğolistan'a sadece kazanç yardımındansa; hizmet, eğitim, sanayi gibi alanlardaki eksiklikleri kapatarak tam demokratikleşmiş ve serbest piyasa ekonomisini benimsemiş bir desteği hedeflemektedir. Bu noktada Moğolistan'ın tam demokratik 
ve bağımsız oluşu ABD için de önem taşıdığı için karşılıklı faydaları oldukça önemlidir. Bölgedeki yeri bakımından en önemli müttefiki olarak sayılabilecek Moğolistan'ın gelişerek çevresine bağımlılığının azalması; ABD 'nin bölgeye ait stratejik planlarında Moğolistan'dan maksimum faydayı elde etmesini sağlayacaktır.

Moğolistan ABD’yi, Rusya ve Çin ile kurduğu denge politikasında üçüncü bir taraf oluşturacak şekilde dahil ederek; küçük ama akıllı devlet özelliği göstermektedir. Bu özellik, küçük devletlerin çevre aktörleri en stratejik şekilde kullanarak, ulusal çıkarlarını ve uluslararası güvenliğini sağlamasının en önemli yoludur. Bu bağlamda küçük devletler yaklaşımının işlevsel olarak kullanılması durumunda, güçlü devletlerle oldukça yakın ilişkiler kurulup; hem siyasi hem de ekonomik olarak kalkınmanın mümkün olduğunu ispatlamaktadır. Sovyetler Birliği döneminden sonra, siyasi ve ekonomik olarak yeniden yapılanan bir devlet olarak Moğolistan siyasi demokratikleşmesini hızla tamamlayıp, uluslararası sistemde bağımsız bir aktör olarak hedeflenen yere ulaşmıştır. Halen devam eden güncel ilişkilerde zaman zaman ortaya çıkan ekonomik bunalımlar ya da diplomatik gerilimlere rağmen ciddi sorunlarla karşılaşmadan, komşuları ve sistemdeki diğer devletler ile güvenliğini tehdit etmeyecek şekilde bir yere sahip olması Moğolistan'ın denge politikasındaki başarısını göstermektedir. Aynı şekilde küçük bir devlet olarak, stratejik adımlar atarak kısa sürede uluslararası sisteme adapte olunmaya örnek teşkil etmektedir. Sonuç olarak ABD'nin bölgesel stratejilerinde Çin ve Rusya etkisinden uzaklaşmış bir Moğolistan ile kuracağı ortaklık amacı ile yaptığ 1 gelişim destekleri; iki ülkenin de ulusal çıkarlarını gözetmektedir. 


\section{Kaynakça}

1. PEDI, R.G. (2016), Theory of International Relations: Small States in the International System, Doktora Tezi, s. 64

2. TOJE, Asle (2010), The Tragedy of Small Power Politics: The Europian Union Under Multipolarity, The Norwegian Atlantic Comittee, 4-2010, s.14

3. MACKINDER, H.J. (1942), Democratic Ideals and Reality, National Defense University Yayınları, Washington, s.78

4. ATWOOD, Christopher P. (2004); "Encyclopedia of Mongolia and the Mongol Empire”, Facts On File Yayınları, New York, s.377

5. https://history.state.gov/countries/mongolia , Erişim Tarihi: 21.03.2017

6. SANDERS, Alan J.K. ( 2003) ; Historical Dictionary of Mongolia, İkinci Baskı, Scarecrow Yayınları, Boston, s. 1 ( Kronoloji)

7. https://www.state.gov/r/pa/ei/bgn/2779.htm , Erişim Tarihi: 25.03.2017

8. DASHTSEREN, Buyantyn (1997), "International Position of Mongolia: Historical Overview", The Mongolian Journal of International Affairs, Say1:4, s. 53

9. CAMPI, Alicia (2005), "Mongolia in Northeast Asia- The New Realities", The Mongolian Journal of International Affairs, No:12 s. 51

10. MILIATE, Brandon Joseph (2011), Small Power: Mongolia's Democratization and Foreign Policy Objectives, Yüksek Lisans Tezi, University of Southern California s. 19

11. LAWRENCE, Susan V (2011), Mongolia: Issues for Congress, Congressional Research Service Yayınları, s. 15

12. PRESS G., BARNATHAN (2012), “ The Leader Can't Lead When The Followers Won't Follow”, Editörler: WILLIAMS K. P. , LOBELL S.E. , JESSE N.G, Beyond Great Powers and Hegemons, Stanford University Yayınları, California, s.12-13

13. https://www.un.int/mongolia/mongolia/mongolia-and-united-nations-0 , Erişim Tarihi: 11.05.2017

14. http://www.community-democracies.org/values/warsaw-declaration/, Erişim Tarihi:12.05.2017

15. http://www.community-democracies.org/mongolia-pledges-usd-150000-for-community-of-democracies/ , Erişim Tarihi:12.05.2017 
16. http://www.nato.int/cps/en/natohq/topics_85297.htm , NATO Resmi İnternet Sitesi, Erişim Tarihi:26.04.2017

17. JARGALSAIKHAN, Mendee (2012), "Finally A New Era in NATOMongolia Relations", Voices From Central Asia, Sayı:1, Haziran 2012, s.4

18. "Joint Statement Between the United States and Mongolia" Resmi Metni, 15 Temmuz 2004, Washington DC

19. 2007 Declaration of Principles for Closer Cooperation Between the United States of America and Mongolia, http://mongolianembassy.us/?attachment_id=1552\#.WNpzqG_yjDc , Erişim Tarihi:28.03.2017

20. Uluslararası Kadın Liderliği Forumu Resmi Konuşması, http://www.cfr.org/women/clintons-remarks-international-womensleadership-forum-july-2012/p28686, Erişim Tarihi:3.05.2017

21. "In the Senate of the United States Resolution" Resmi Belgesi, https://mongolia.usembassy.gov/root/media/pdf/mdm11426.pdf, Erişim Tarihi:3.05.2017

22. BREZINSKI, Z. (1997), Büyük Satranç Tahtası, İnk1lap Kitapevi, İstanbul, s.63

23. BREZINSKI, Z. (1997), Büyük Satranç Tahtası, İnkılap Kitapevi, İstanbul, s. 21

24. BREZINSKI, Z. (2012), Stratejik Vizyon: Amerika ve Küresel Güç Buhranı, Timaş Yayınları, İstanbul, s.23

25. CIA Resmi İnternet Sitesi; https://www.cia.gov/library/publications/the-worldfactbook/geos/mg.html , Erişim Tarihi:27.12.2016

26. YİĞİT, Süreyya (2013), "Mongolia's Path to Economic Prosperity and Political Liberalisation”, Ortadoğu Analiz, Eylül 2013, Cilt: 5, Say1:57, s. 11

27. https://mongolia.usembassy.gov/20th_anniversary_usaid/mongolia2.ht ml , ABD Resmi Arşivi, Erişim Tarihi:5.05.2017

28. http://mongolianembassy.us/trade-and-investment/\#.WReR7fnyjDc, Erişim Tarihi:14.05.2017

29. https://ustr.gov/countries-regions/china-mongolia-taiwan/mongolia , Erişim Tarihi:13.05.2017

30. USAID Country Profile Report 2017, https://scms.usaid.gov/sites/default/files/documents/1861/Mongolia_C ountry_Profile_0.pdf ,Erişim Tarihi: 9.05.2017 